Article

\title{
Pure Hydrogen Production in Membrane Reactor with Mixed Reforming Reaction by Utilizing Waste Gas: A Case Study
}

\author{
Seyyed Mohammad Jokar ${ }^{1}$, Mohammad Reza Rahimpour ${ }^{1}$, Alireza Shariati ${ }^{1}$, \\ Adolfo Iulianelli ${ }^{2, *}$, Giuseppe Bagnato ${ }^{2}$, Antonio Vita ${ }^{3}$, Francesco Dalena ${ }^{4}$ and \\ Angelo Basile 2,* \\ 1 Department of Chemical Engineering, School of Chemical and Petroleum Engineering, \\ Shiraz University, Shiraz 71345, Iran; s.m.jokar@gmail.com (S.M.J.); \\ rahimpor@shirazu.ac.ir (M.R.R.); shariati@shirazu.ac.ir (A.S.) \\ 2 Institute on Membrane Technology of the National Research Council of Italy (CNR-ITM), \\ via P. Bucci Cubo 17/C c/o University of Calabria, Rende (CS) 87036, Italy; gb17@hw.ac.uk \\ 3 Institute of Advanced Technologies for Energy "Nicola Giordano" of the National Research Council of \\ Italy (CNR-IITAE), Via S. Lucia sopra Contesse n. 5, Messina 98126, Italy; antonio.vita@itae.cnr.it \\ 4 Department of Chemistry, University of Calabria, Via P. Bucci, Rende (CS) 87036, Italy; dalena.ch@gmail.com \\ * Correspondence: a.iulianelli@itm.cnr.it (A.I.); a.basile@itm.cnr.it (A.B.); Tel.: +39-098-449-2011 (A.I.); \\ +39-098-449-2013 (A.B.); Fax: +39-098-440-2103 (A.I. \& A.B.)
}

Academic Editor: Catherine Charcosset

Received: 5 July 2016; Accepted: 13 September 2016; Published: 20 September 2016

\begin{abstract}
A rise in $\mathrm{CO}_{2}$ and other greenhouse gases' concentration from gas refinery flares and furnaces in the atmosphere causes environmental problems. In this work, a new process was designed to use waste gas (flue gas and flare gas) of a domestic gas refinery to produce pure hydrogen in a membrane reactor. In particular, the process foresees that the energy and $\mathrm{CO}_{2}$ content of flue gas can provide the heat of the mixed reforming reaction to convert flare gas into hydrogen. Furthermore, the characteristics of the feed stream were obtained via simulation. Then, an experimental setup was built up to investigate the performance of a membrane reactor allocating an unsupported dense Pd-Ag membrane at the mentioned conditions. In this regard, a $\mathrm{Ni} / \mathrm{CeO}_{2}$ catalyst was loaded in the membrane reformer for mixed reforming reaction, operating at $450{ }^{\circ} \mathrm{C}$, in a pressure range between 100 and $350 \mathrm{kPa}$ and a gas hourly space velocity of around $1000 \mathrm{~h}^{-1}$. The experimental results in terms of methane conversion, hydrogen recovery and yield, as well as products' compositions are reported. The best results of this work were observed at $350 \mathrm{kPa}$, where the MR was able to achieve about $64 \%$, $52 \%$ and $50 \%$ for methane conversion, hydrogen yield and recovery, respectively. Furthermore, with the assistance of the experimental tests, the proposed process was simulated in the scaling up to calculate the needed surface area for MR in the domestic gas refinery.
\end{abstract}

Keywords: process design; mixed reforming reaction; membrane reactor; hydrogen production

\section{Introduction}

\subsection{Flare and Flue Gas}

In this century, air pollution and global warming due to the high emission of greenhouse gases (GHGs) are big challenging issues. The primary GHGs in the Earth's atmosphere are $\mathrm{CO}_{2}, \mathrm{CH}_{4}$, water vapor and ozone. Amongst them, $\mathrm{CO}_{2}$ and $\mathrm{CH}_{4}$ contribute to $9 \%-26 \%$ and $4 \%-9 \%$ of the total greenhouse effect, respectively, and hence, mitigation of both of these gases is of a major concern [1].

The flare gas and flue gas, which are produced from furnaces in oil and gas refineries, are the big sources of GHGs, especially $\mathrm{CH}_{4}$ and $\mathrm{CO}_{2}$ (the World Bank estimated that the annual volume of 
associated gas being flared and vented is about 110 billion cubic meters). Introducing a method to recover and reuse these gases can constitute an effective approach to control the GHGs' level.

Furthermore, besides the environmental problems, the huge amounts of energy being wasted by exhaust flue gas should be considered [2]. Some refineries plan to build cogeneration facilities and based on gas turbines burning refinery gases $[3,4]$ or refinery gases and natural gas $[4,5]$.

At the scientific level, it is worth noting that Rahimpour et al. proposed methods for recovering flare gas instead of conventional gas burning in different refineries of Iran [6-8]. Abdulrahman et al. investigated the improvements in Egypt's oil and gas industry by the implementation of flare gas recovery [9]. In the meantime, some researchers studied $\mathrm{CO}_{2}$ capturing [10-13] and hydrogen production [14-16] by using flue gas as a source in order to save fuel consumption and reducing pollutants' emissions from furnaces.

\subsection{Hydrogen Production with Mixed Reforming}

Nowadays, the production of hydrogen in reforming processes has attracted particular interest, because this is considered as one of the most important energy carriers [17]. Hydrogen can be used in combustion engines or, under significative purity, in the proton exchange membrane fuel cells (PEMFCs) supplying the generation of electricity [18].

Although steam reforming consumes high amounts of energy, it is considered as the most attractive fuel processing for hydrogen and synthesis gas production [19-21].

Many studies in the literature deal with a number of fuels used for the steam reforming reaction in traditional reactors (TRs). These fuels can include non-renewable fossil fuels, like natural gas, petroleum and renewable raw materials, such as biogas.

Besides steam reforming of methane, which is the most used reforming process for hydrogen generation in industry, there are many studies on $\mathrm{CO}_{2}$ (dry) reforming of methane over different catalysts. Most of them are realized in TRs by using Ni-based catalysts [22-27]. As a main drawback of, especially, the dry reforming of methane, several authors demonstrated that carbon deposition on the catalyst is very fast [22]. More recently, some researches focused on the simultaneous steam and carbon dioxide reforming of methane, known as 'mixed reforming' [28-31]. It has been shown that, besides the effect of temperature and the type of catalyst on the reaction system, the presence of carbon dioxide could be effective in methane steam reforming. It would enhance the conversion of methane, and it can have a positive influence on the hydrogen production and the $\mathrm{H}_{2} / \mathrm{CO}$ syngas ratio [32-35]. Furthermore, other studies demonstrated that the carbon deposition (which is very high in dry reforming) is drastically reduced when the steam and $\mathrm{CO}_{2}$ reforming reactions are carried out simultaneously [25,35-37].

The mixed reforming reactions are represented by the equations reported in the following:

$$
\begin{array}{ccl}
\mathrm{CH}_{4}+\mathrm{H}_{2} \mathrm{O} \Leftrightarrow \mathrm{CO}+3 \mathrm{H}_{2} \quad \Delta H=+206.2 \mathrm{~kJ} / \mathrm{mol} & \text { (steam reforming) } \\
\mathrm{CH}_{4}+\mathrm{CO}_{2} \Leftrightarrow 2 \mathrm{CO}+2 \mathrm{H}_{2} \quad \Delta H=+247.9 \mathrm{~kJ} / \mathrm{mol} & \left(\mathrm{CO}_{2}\right. \text { (dry) reforming) } \\
\mathrm{CO}+\mathrm{H}_{2} \mathrm{O} \Leftrightarrow \mathrm{CO}_{2}+\mathrm{H}_{2} \quad \Delta H=-41 \mathrm{~kJ} / \mathrm{mol} & \text { (water }- \text { gas shift) }
\end{array}
$$

The recent research studies on the mixed reforming process have been mainly focused on catalyst performance studies [38-41]. Active metals, including noble metals [42-46] and transition metals [47-53], could be used to prepare catalyst for mixed reforming. However, the noble metals have a higher coke resistivity in comparison to transition metals, but their main drawbacks are represented by their high prices and the low availability of noble metals [54]. For these reasons, nickel is a good substitution for noble metals in reforming processes, $[55,56]$ and in the specialized literature, several studies dealt with the utilization of Ni-based catalyst for mixed steam reforming [57-66]. 


\subsection{Pd-Based Membrane}

It is well recognized that membrane reactor (MR) technology is a well-established reality in the production of hydrogen through reforming processes, as an option to the TRs [46,67]. Dense metal membranes can operate at medium pressures and temperatures (for example, for steam reforming and water-gas shift reactions) [68]. In the field of hydrogen production, separation and purification from COx for fuel cell supplying, both dense self-supported and composite Pd-based membranes have the peculiarity of being hydrogen perm-selective with respect to all of the other gases. Thus, both kinds of membranes, when housed in MRs, make it possible to overcome the thermodynamic restrictions of equilibrium-limited reactions due to the removal of hydrogen from the reaction side for the selective permeation through the membrane ("shift effect"). Moreover, due to Le Chatelier's principle, the reaction can be shifted towards the reaction products, with a consequent enhancement of the conversion and with the further benefit of collecting high grade hydrogen in the permeate side of the MR. Therefore, dense self-supported Pd-based MRs seem to be more adequate over other technologies to generate PEMFC-grade hydrogen due to the full hydrogen perm-selectivity of the membrane, while, depending on the finite value of the hydrogen perm-selectivity of the composite membrane, the purified hydrogen can be supplied to other kinds of fuel cells or to high temperature PEMFCs, whose CO content can be up to 20,000 ppm [67,69-75].

Regarding the purpose of this study, other groups proposed a process design associated with MR integration, [56,76] and based on the advantages associated with MR technology utilization reported above, in this work, we proposed a dense unsupported Pd-Ag MR instead of a TR for producing PEMFC-grade $\mathrm{H}_{2}$ from waste gases (flare gas and flue gas) of a domestic gas refinery.

\section{Gas Refinery}

\subsection{Domestic Gas Refinery}

A domestic gas refinery has been placed in Iran to dehydrate the produced gas and stabilize the accompanied condensate from two different gas reservoirs. One of these reservoirs contains sour gas, and the other one contains sweet gas. Every day, about 1400 million standard cubic feet (MMscf) of gas are fed to this plant. In a recent work, a simulation study was performed by using the steady state process simulation software (licensed by the Oil Company, Iran) with a hardware lock of S/N 08225 , demonstrating that, in this refinery, more than 4.0 MMscf/d of gas are flared in three units ("100", "300", "600") [6]. The composition and conditions of gathered flare gas are resumed in Tables 1 and 2.

Table 1. Composition of gathered flare gas [6].

\begin{tabular}{cc}
\hline Component & Fuel Gas \\
\hline Methane & $88.0 \%$ \\
Ethane & $3.5 \%$ \\
Propane & $0.8 \%$ \\
Nitrogen & $3.3 \%$ \\
$\mathrm{CO}_{2}$ & $3.0 \%$ \\
$i$-Butane & $0.2 \%$ \\
$n$-Butene & $0.3 \%$ \\
$\mathrm{C}_{5+}$ & $0.5 \%$ \\
$\mathrm{H}_{2} \mathrm{O}$ & $0.3 \%$ \\
$\mathrm{H}_{2} \mathrm{~S}$ & $77 \mathrm{ppm}$ \\
Benzene & $67 \mathrm{ppm}$ \\
Toluene & $73 \mathrm{ppm}$ \\
\hline
\end{tabular}

Figure 1 shows the process flow diagram of "Unit 300" of the aforementioned domestic gas refinery. Supplementary Figure S1 shows the 3D scheme of the "Unit 300” furnace and its surroundings. 
Table 2. Conditions of gathered flare gas [6].

\begin{tabular}{ccc}
\hline Conditions & Unit & Value \\
\hline Temperature & ${ }^{\circ} \mathrm{C}$ & 30.27 \\
Pressure & $\mathrm{kPa}$ & 801.3 \\
Molar Flow & $\mathrm{kg}-\mathrm{mole} / \mathrm{h}$ & 208.0 \\
Mass Flow & $\mathrm{kg} / \mathrm{h}$ & 3859 \\
Molar Enthalpy & $\mathrm{kJ} / \mathrm{kg}-$ mole & $-8.361 \times 10^{4}$ \\
Molar Entropy & $\mathrm{kJ} / \mathrm{kg}-$ mole.${ }^{\circ} \mathrm{C}$ & 169.7 \\
Heat Flow & $\mathrm{kJ} / \mathrm{h}$ & $-1.739 \times 10^{7}$ \\
\hline
\end{tabular}

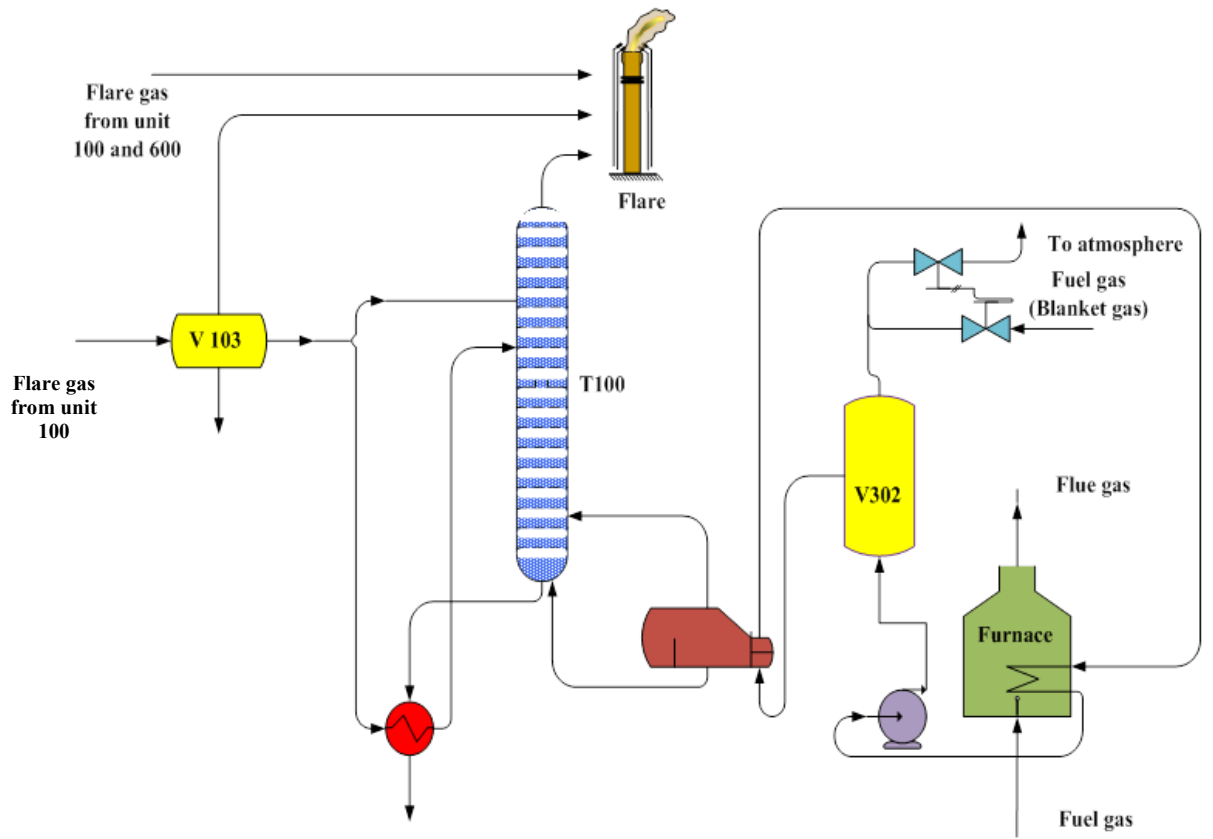

Figure 1. Process flow diagram of "Unit 300" of the domestic gas refinery.

In this refinery, $20 \%$ excess air is used for the furnace. Therefore, a small amount of CO and oxygen is present in the flue gas.

The composition and conditions of fuel gas and flue gas are shown in Tables 3 and 4. Fuel gas is supplied from a pipeline in "Unit 100", which comes from a sweet gas reservoir. This made fuel gas and flue gas free of hydrogen sulfide.

Table 3. Composition of fuel gas and flue gas.

\begin{tabular}{ccc}
\hline Component & Fuel Gas & Flue Gas \\
\hline Methane & $91.0 \%$ & Trace \\
Ethane & $1.3 \%$ & Trace \\
Propane & $0.3 \%$ & Trace \\
Nitrogen & $6.0 \%$ & $63.3 \%$ \\
$\mathrm{CO}_{2}$ & $0.8 \%$ & $11.0 \%$ \\
$\mathrm{CO}$ & 0.0 & $2 \mathrm{ppm}$ \\
$\mathrm{NO}_{x}$ & 0.0 & Trace \\
Oxygen & 0.0 & $4.1 \%$ \\
$i$-Butane & $0.1 \%$ & 0 \\
$n$-Butene & $0.2 \%$ & 0 \\
$\mathrm{C}_{5+}$ & $0.2 \%$ & 0 \\
$\mathrm{H}_{2} \mathrm{O}$ & $8 \mathrm{ppm}$ & $21.6 \%$ \\
$\mathrm{H}_{2} \mathrm{~S}$ & 0.0 & 0 \\
& &
\end{tabular}


Table 4. Conditions of fuel gas and flue gas.

\begin{tabular}{cccc}
\hline \multirow{2}{*}{ Conditions } & Unit & \multicolumn{2}{c}{ Value } \\
\cline { 3 - 4 } & & Fuel Gas & Flue Gas \\
\hline Temperature & ${ }^{\circ} \mathrm{C}$ & 29 & 873 \\
Pressure & $\mathrm{kPa}$ & 801 & 101 \\
Molar Flow & $\mathrm{kg}-\mathrm{mole} / \mathrm{h}$ & 84.7 & 756.4 \\
Mass Flow & $\mathrm{kg} / \mathrm{h}$ & 1478 & 21,030 \\
Molar Enthalpy & $\mathrm{kJ} / \mathrm{kg}-\mathrm{mole}$ & $-7.36 \times 10^{4}$ & $-6.5 \times 10^{4}$ \\
Molar Entropy & $\mathrm{kJ} / \mathrm{kg}-\mathrm{mole} \cdot{ }^{\circ} \mathrm{C}$ & 167 & 211 \\
Heat Flow & $\mathrm{kJ} / \mathrm{h}$ & $-6.23 \times 10^{6}$ & $-4.94 \times 10^{7}$ \\
\hline
\end{tabular}

\subsection{Process Design for Hydrogen Generation}

Figure 2 shows a schematic diagram of the proposed process for pure hydrogen generation. The mixture of sweet flare gas (mostly containing methane), steam (from steam generation unit) and $\mathrm{CO}_{2}$ (from $\mathrm{CO}_{2}$ recovery unit) is preheated by heat exchanging and, then, fed to the MR, heated by flue gas (mostly containing $\mathrm{CO}_{2}$ ), for carrying out the mixed reforming reaction at the set operating temperature. Supplementary Figure $\mathrm{S} 2$ shows a schematic diagram of the $\mathrm{CO}_{2}$ recovery unit, in which the mixture of flue gas and the retentate stream (after a polymeric membrane separation useful for separating $\mathrm{CH}_{4}$ and $\mathrm{H}_{2}$ ) pass to the absorber after cooling by a flue gas cooler.

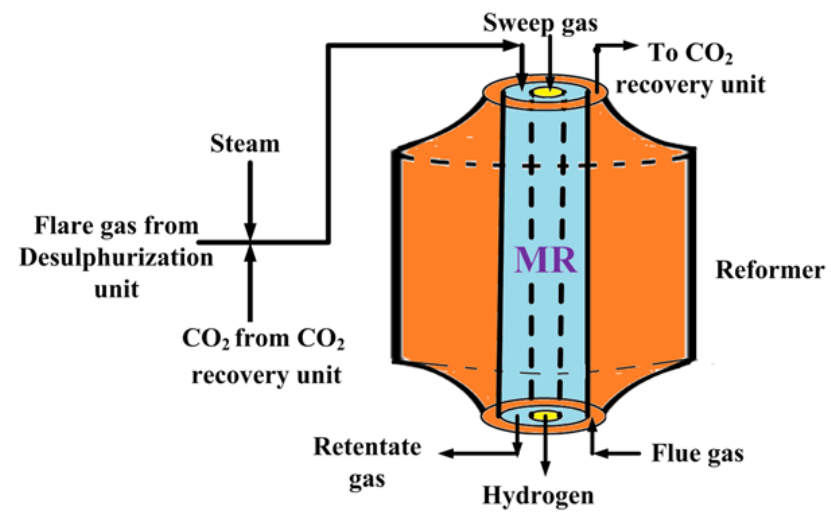

Figure 2. Schematic diagram of the proposed process for hydrogen generation with utilization of flare gas and flue gas.

The flare gas stream contains a small amount of hydrogen sulfide that was previously removed by a desulphurization unit to avoid the Pd-Ag membrane poisoning and of the catalyst, as well. The hydrogen produced during the reaction and permeated through the dense Pd-Ag as a pure stream constitutes the outgoing permeate stream for PEMFC supplying. The other outgoing stream (retentate) is directed to the $\mathrm{CO}_{2}$ recovery unit because it is rich in $\mathrm{CO}_{2}$ after a polymeric membrane separation step to separate $\mathrm{CH}_{4}$ and $\mathrm{H}_{2}$ from this stream, indirectly contributing to mitigating the GHGs in the atmosphere.

In this work, a novel process is proposed to produce pure hydrogen from waste gases (flare gas and flue gas) of a domestic gas refinery through the utilization of a Pd-Ag MR. The used data related to the characteristics of the feed stream to be flowed into the MR were obtained by a simulation of the aforementioned refinery (the same software as reported in [6] was used). Then, the composition and conditions of feed the stream before entering in the MR are shown in Tables 5 and 6 . The MR was operated at $450{ }^{\circ} \mathrm{C}$ (as the maximum temperature limit of the used Pd-Ag membrane) and between 150 and $350 \mathrm{kPa}$ (the latter representing the maximum pressure limit of the used $\mathrm{Pd}-\mathrm{Ag}$ membrane). 
Table 5. Estimated composition of feed stream for the MR.

\begin{tabular}{cc}
\hline Component & {$[\%]$} \\
\hline Methane & 17.9 \\
Ethane & 0.8 \\
Propane & 0.4 \\
Nitrogen & 0.7 \\
$\mathrm{CO}_{2}$ & 9.1 \\
$\mathrm{CO}$ & 0.0 \\
$\mathrm{H}_{2} \mathrm{O}$ & 71.1 \\
$\mathrm{H}_{2} \mathrm{~S}$ & 0.0 \\
\hline
\end{tabular}

Table 6. Estimated conditions of the feed stream for the MR.

\begin{tabular}{ccc}
\hline Conditions & Unit & Value \\
\hline Temperature & ${ }^{\circ} \mathrm{C}$ & 160 \\
Pressure & $\mathrm{kPa}$ & 350.3 \\
Molar Flow & $\mathrm{kg}-\mathrm{mole} / \mathrm{h}$ & 934 \\
Mass Flow & $\mathrm{kg} / \mathrm{h}$ & 18,990 \\
\hline
\end{tabular}

\section{Experimental Procedure}

\subsection{Experimental Setup}

An experimental setup was built to investigate the production of PEMFC-grade hydrogen from mixed reforming of a model feed gas mixture (flue gas + flare gas + steam) by means of a dense $\mathrm{Pd}_{77}-\mathrm{Ag}_{23} \mathrm{MR}$ packed with a non-commercial $\mathrm{Ni}(7.5 \mathrm{wt} \%) / \mathrm{CeO}_{2}$ catalyst provided by CNR-ITAE (Messina, Italy), chosen for its low cost and high coke resistance [77,78].

The MR consists of a tubular stainless steel module (length $280 \mathrm{~mm}$, i.d. $20 \mathrm{~mm}$ ) containing a tubular commercial dense self-supported Pd-Ag membrane provided by Johnson \& Matthey Co. (Royston, UK), with a wall thickness of $150 \mathrm{m \mu m}$, o.d. $10 \mathrm{~mm}$ and $10 \mathrm{~cm}$ as the length (Figure 3).

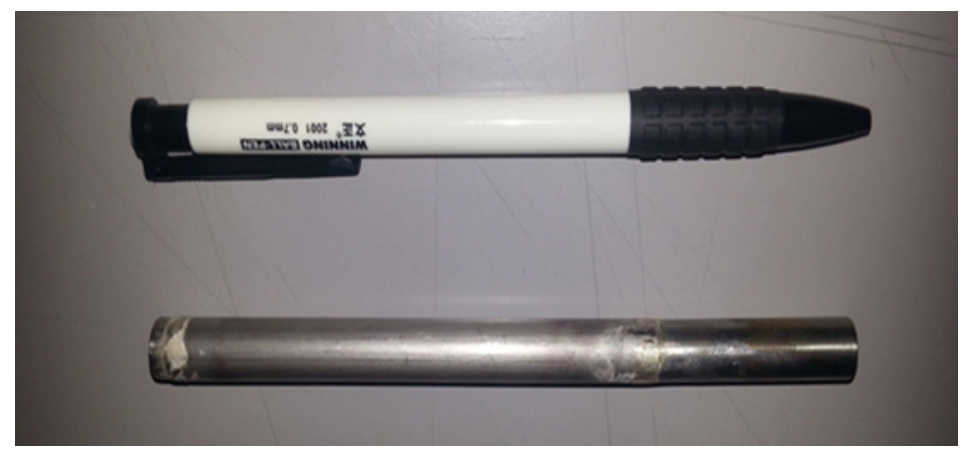

Figure 3. The dense Pd-Ag membrane.

The MR is heated by means of a heating tape connected to a temperature controller. The operating temperature is measured by a thermocouple inserted into the MR lumen. The reaction pressure is regulated by means of a back-pressure controller placed at the outlet side of the retentate stream. The permeate pressure is kept constant during the whole experimental campaign at $100 \mathrm{kPa} . \mathrm{CH}_{4}$, $\mathrm{CO}_{2}, \mathrm{~N}_{2}$ and pure $\mathrm{H}_{2}\left(\mathrm{~N}_{2}\right.$ also used as the standard gas and $\mathrm{H}_{2}$ used for the catalyst reduction) are supplied by means of Brooks Instruments $5850 \mathrm{~S}$ mass-flow controllers, driven by a Lira (Turin, Italy) software. $\mathrm{H}_{2} \mathrm{O}$ is supplied by means of a volumetric pump (type FMQG6) provided by General Control (Milan, Italy). 
$\mathrm{CH}_{4}, \mathrm{CO}_{2}, \mathrm{~N}_{2}$ and steam feed molar flow rates are $1.03 \times 10^{-3}, 5.27 \times 10^{-4}, 7.43 \times 10^{-4}$ and $4.11 \times 10^{-3} \mathrm{~mol} / \mathrm{min}$, respectively, while the $\mathrm{CH}_{4} / \mathrm{CO}_{2} / \mathrm{H}_{2} \mathrm{O}$ reactant feed ratio is $1 / 0.5 / 4$ with a GHSV of $1020 \mathrm{~h}^{-1}$. This feed ratio is chosen taking into account the simulation results summarized in Table 5 and kept constant during all of the experimental tests. $\mathrm{N}_{2}$ was also used as a sweep-gas (counter-current configuration with respect to the feed) and flowed into the MR permeate side with a volume flow rate of $1.27 \times 10^{-3} \mathrm{~mol} / \mathrm{min}$.

The water was vaporized in a pre-heater prior to entering the MR reaction side.

The outlet stream from the retentate zone is passed through a cold trap in order to remove the unreacted $\mathrm{H}_{2} \mathrm{O}$, and then, the retentate and the permeate streams are analyzed simultaneously by means of a temperature-programmed HP 6890 gas chromatograph (GC) provided by Hewlett-Packard (Palo Alto, CA, USA). To ensure the reproducibility of the results, each experimental point of this work represents an average value of, at least, 10 experimental results, taken in around 140 min per reaction test at steady state conditions.

\subsection{Permeation Tests and Catalyst Activation}

Prior to the reaction tests, the Pd-Ag membrane was characterized under pure gas permeation in the absence of an active sweep. Then, pure $\mathrm{N}_{2}$ and $\mathrm{H}_{2}$ were flowed in the MR at 350,400 and $450{ }^{\circ} \mathrm{C}$. The volume flow rate of permeating hydrogen through the membrane is measured by means of a bubble flow meter (the volume of the bubble flow meter used to measure the $\mathrm{H}_{2}$ permeating flow was $10 \mathrm{~mL}$ ). $\mathrm{N}_{2}$ was used only to check whether the membrane is permeable to another gas besides $\mathrm{H}_{2}$ and to ensure its full hydrogen perm-selectivity (the volume of the bubble flow meter used to check the presence of $\mathrm{N}_{2}$ permeating flow was $100 \mathrm{~mL}$ ).

Then, the reactor was cooled down at room temperature and packed with $2.8 \mathrm{~g}$ of $\mathrm{Ni} / \mathrm{CeO}_{2}$ catalyst. Successively, the MR was heated up again to $450{ }^{\circ} \mathrm{C}$ for realizing the reaction tests in the reaction pressure range between 100 and $350 \mathrm{kPa}$. Before the reaction, the catalyst was preheated using $\mathrm{N}_{2}$ at $450{ }^{\circ} \mathrm{C}$ under atmospheric pressure for $3 \mathrm{~h}$ and, afterwards, reduced by using $\mathrm{H}_{2}$ $\left(1.5 \times 10^{-3} \mathrm{~mol} / \mathrm{min}\right)$ at the same temperature for $2 \mathrm{~h}$.

It should be considered that, in order to ensure the accuracy of the experimental results, after each reaction test, the hydrogen permeating flux through the dense commercial Pd-Ag membrane was measured and compared to the values obtained during the permeation tests.

\subsection{Equations}

The following equations are used for calculating the methane conversion and hydrogen recovery:

$$
\begin{gathered}
\text { Methane conversion }(\%)=\frac{\mathrm{CH}_{4-\text { in }}-\mathrm{CH}_{4-\text { out }}}{\mathrm{CH}_{4-\text { in }}} \times 100 \\
\text { Hydrogen recovery }(\%)=\frac{\mathrm{H}_{2-\text { perm }}}{\left(\mathrm{H}_{2-\text { perm }}+\mathrm{H}_{2-\text { ret }}\right)} \times 100 \\
\text { Hydrogen yield }(\%)=\frac{\left(\mathrm{H}_{2-\text { perm }}+\mathrm{H}_{2-\text { ret }}\right)}{3 \mathrm{CH}_{4-\text { in }}} \times 100
\end{gathered}
$$

In Equations (4)-(6), the subscript "OUT" means the total outlet molar flow rate of $\mathrm{CH}_{4}$, while "IN" refers to its inlet molar flow rate $(\mathrm{mol} / \mathrm{min})$, while "perm" and "ret" mean the hydrogen molar flow rate $(\mathrm{mol} / \mathrm{min})$ in the permeate and retentate side, respectively.

Equation (7) represents the Sieverts-Fick law useful for describing the hydrogen permeating flux $J_{\mathrm{H}_{2}}$ through the dense Pd-Ag membrane. As reported below, the exponent of the hydrogen partial pressures in the retentate and permeate sides is equal to 0.5 , a typical value for full hydrogen 
perm-selective membranes when the bulk diffusion of $\mathrm{H}_{2}$ through the palladium layers is the rate-limiting step at low pressure.

$$
J_{H_{2}}=\frac{P_{H_{2}}\left(p_{H_{2}, r e t}^{0.5}-p_{H_{2}, p e r m}^{0.5}\right)}{\delta}
$$

Equation (8) describes the relationship between the hydrogen permeability $\left(P_{\mathrm{H}_{2}}\right)$ with the temperature as an Arrhenius-like law.

$$
P_{H_{2}}=P_{H_{2}}^{0} \exp \left(-\frac{E_{a}}{R T}\right)
$$

In the equations reported above: $P_{H_{2}}^{0}, E_{a}, R, T$ and $\delta$ represent the pre-exponential factor, apparent activation energy, universal gas constant, absolute temperature and the Pd-Ag membrane thickness, respectively. Furthermore, $p_{H_{2}, \text { ret }}^{0.5}$ and $p_{H_{2}, \text { perm }}^{0.5}$ indicate the hydrogen partial pressure in the retentate and permeate zones.

\section{Results and Discussion}

\subsection{Hydrogen Permeation Tests}

During the permeation tests, the $\mathrm{H}_{2}$ volume flow rate permeating through the membrane was evaluated in the pressure and temperature ranges between 100 and $300 \mathrm{kPa}$ and 350 and $450{ }^{\circ} \mathrm{C}$, respectively. At the same conditions, $\mathrm{N}_{2}$ permeation was also checked, observing the absence of its permeation in the whole experimental campaign. The calculated $\mathrm{E}_{\mathrm{a}}$ and $P_{\mathrm{H}_{2}}^{0}$ for the dense Pd-Ag membrane are $13,412 \mathrm{~J} / \mathrm{mol}$ and $2.16 \times 10^{-7} \mathrm{~mol} / \mathrm{m} \cdot \mathrm{s} \cdot \mathrm{Pa}^{0.5}$, respectively.

\subsection{Reaction Tests}

According to the simulation results reported in Table 6, the operating temperature for the MR was kept constant at $450^{\circ} \mathrm{C}$ in the whole experimental campaign of the reaction tests, and the effect of pressure on the reaction conversion, hydrogen recovery and hydrogen yield was investigated.

However, due to the low composition of propane and ethane, they were neglected in the real feeding mixture. In Figures 4-6, methane conversion, hydrogen yield and hydrogen recovery are sketched at different pressures and $450{ }^{\circ} \mathrm{C}$.

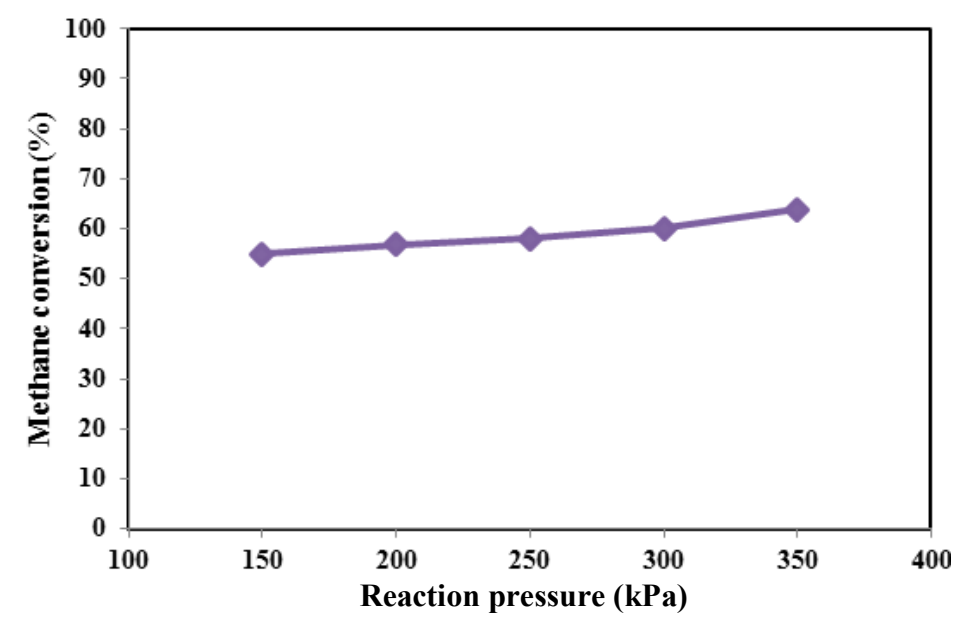

Figure 4. Methane conversion versus reaction pressure at $450{ }^{\circ} \mathrm{C}$ for $\mathrm{MR}$. 


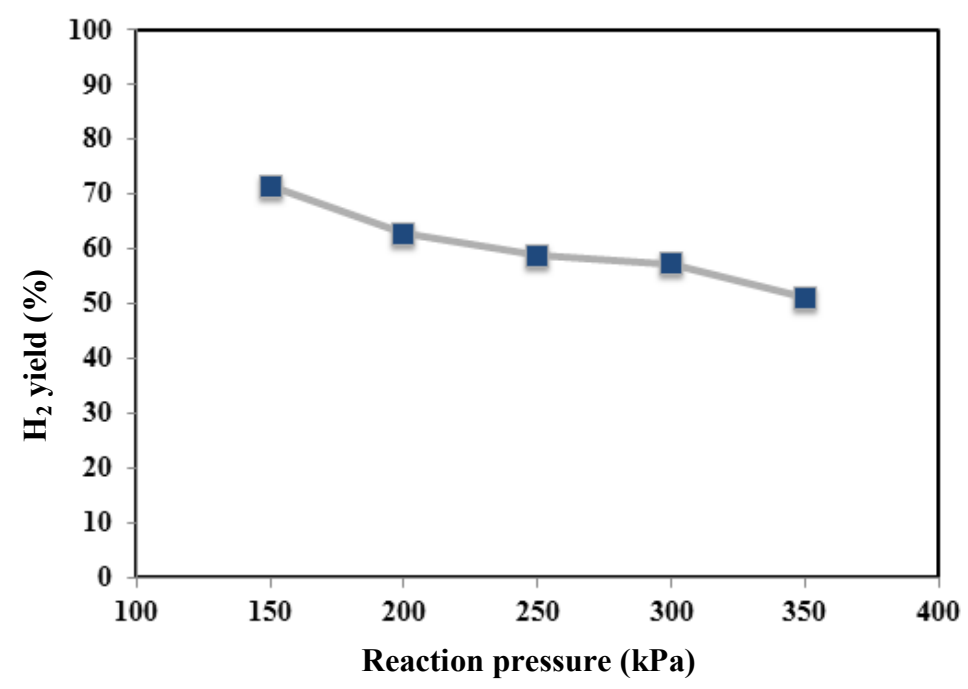

Figure 5. Hydrogen yield versus reaction pressure at $450{ }^{\circ} \mathrm{C}$ for $\mathrm{MR}$.

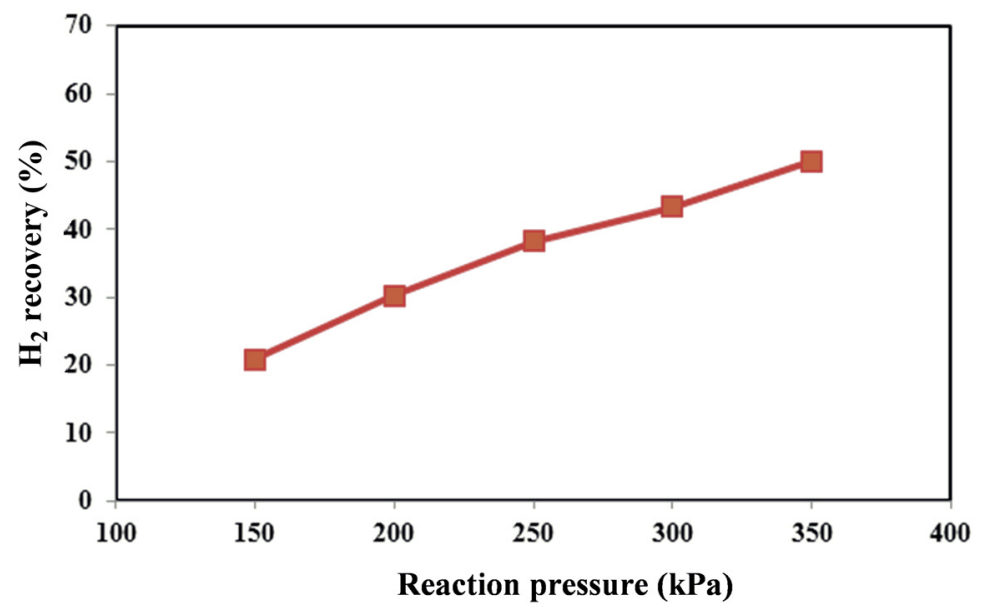

Figure 6. Hydrogen recovery versus reaction pressure at $450{ }^{\circ} \mathrm{C}$ for $\mathrm{MR}$.

Since the considered reforming reactions proceed with the increase of the moles' number, in a $\mathrm{TR}$, it would be expected that, from a thermodynamic point of view, higher methane conversions could be obtained at lower pressures. On the contrary, in the Pd-Ag MR by increasing the reaction pressure, an increase of the hydrogen permeation driving force is induced, favoring a higher hydrogen removal from the reaction side towards the permeate side with a consequent higher hydrogen recovery (Figure 6). Due to Le Chatelier's principle, this makes possible a shift of the reforming reactions from the reactants to the products with a consequent enhancement of the conversion (shift effect) (Figure 4).

Furthermore, by using the non-commercial Ni-based catalyst in the MR, no coke formation was noticed at the operating conditions investigated in this work. As the best result, at $450{ }^{\circ} \mathrm{C}$, the maximum methane conversion and hydrogen recovery were achieved at $350 \mathrm{kPa}$ of about $64 \%$ and $50 \%$, respectively. On the contrary, the hydrogen yield showed a decrease from 350 down to $150 \mathrm{kPa}$ (Figure 5).

Figure 7 shows the composition of the gaseous products in the retentate zone versus pressure. It confirms that, at a higher pressure, although the $\mathrm{CO}_{2}$ is consumed in the dry reforming reaction (Equation (2)), $\mathrm{CO}_{2}$ content increases due to the higher conversion in the steam reforming reaction (Equation (1)). Furthermore, at higher pressure, the retentate stream is more concentrated in $\mathrm{CO}_{2}$, 
useful for further treatment of $\mathrm{CO}_{2}$, via polymeric membrane separation from $\mathrm{CH}_{4}$ and $\mathrm{H}_{2}$ and its storage through the $\mathrm{CO}_{2}$ recovery unit.

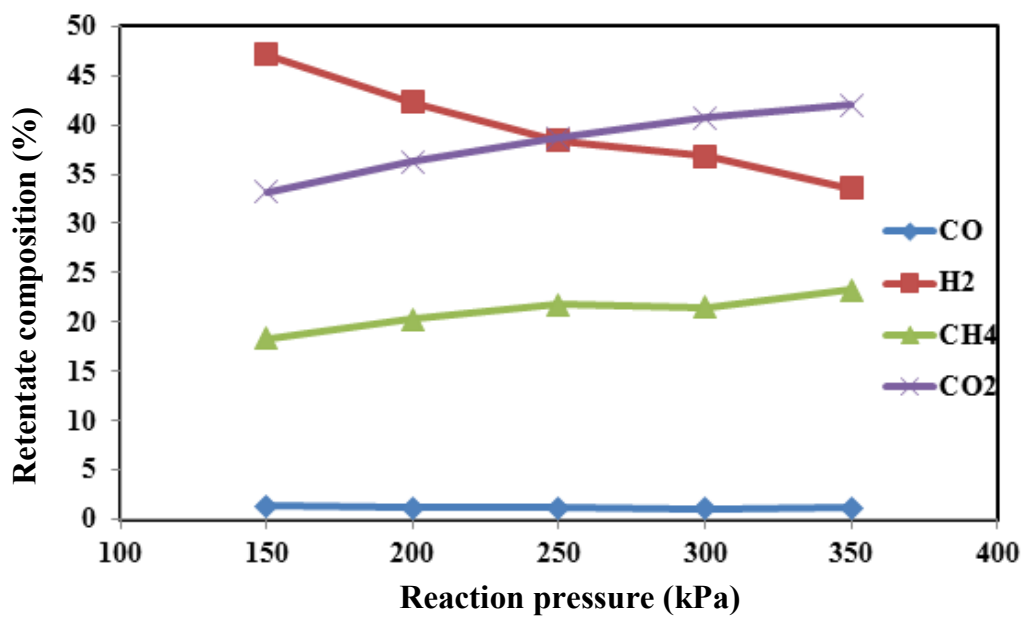

Figure 7. The composition of the gaseous products in retentate zone of the MR versus pressure.

In the meantime, the hydrogen composition decreases because of the higher hydrogen recovery at higher pressures.

\section{MR for the Domestic Gas Refinery}

This section attempts the calculation of the surface area and hydrogen production of the MR for the proposed process in the domestic gas refinery.

In practice, the scale-up of the membrane system should be useful to calculate the membrane area for the aforementioned process, with separation data coming from the previous experimental results.

In this regard, according to what was proposed by Gooding [79] for steady state plug flow membrane systems, the following equation is applicable:

$$
W z / Q_{0}=\text { constant }
$$

In this equation, $W$ and $Q_{0}$ are the membrane area per unit length in the z-direction and the initial volumetric flow rate of the feed in the retentate zone, respectively. It is obvious that the product $\mathrm{Wz}$ gives the total membrane area requirement.

By using the scale-up method [79], the calculations showed that, if we consider a uniform hydrogen distribution in retentate zone, the membrane area should be $930 \mathrm{~m}^{2}$, and $150 \mathrm{~kg} / \mathrm{h}(3.6 \mathrm{t} / \mathrm{d})$ hydrogen could be produced from the proposed process at $350 \mathrm{kPa}$ and $450{ }^{\circ} \mathrm{C}$.

It should be mentioned that, although the surface area of the simulated MR for the domestic gas refinery is relatively high because of using flare gas as an inlet feed, the costs regarding natural gas feed are eliminated. Furthermore, the economic advantages are gained from low-temperature operation and using the heat of flue gas as a source of energy for the mixed reforming reaction. These advantages besides the benefits of the mixed reforming reaction make the proposed process attractive compared to the conventional processes for hydrogen production in large-scale plants.

Nevertheless, unsupported Pd-based membranes offer full $\mathrm{H}_{2}$ perm-selectivity with respect to all of the other gases, but owing to the low availability of $\mathrm{Pd}$ in nature, they result in being very expensive. An alternative option could be the supported thin Pd-membranes, stable at high temperatures and exhibiting relatively high hydrogen permeability, resulting in being available at moderate cost due to the lower content of palladium. 


\section{Conclusions}

In this research, a novel process was designed to produce hydrogen from waste gas (flare gas + flue gas) of a domestic gas refinery. The proposed process was simulated to find the condition of the feed stream for producing pure hydrogen in a MR. Then, an experimental setup at bench scale was built up for evaluating the hydrogen production via the mixed reforming reaction through an MR housing a commercial dense Pd-Ag membrane, packed with a $\mathrm{Ni} / \mathrm{CeO}_{2}$ catalyst at $450{ }^{\circ} \mathrm{C}$, pressure range of $100-350 \mathrm{kPa}$ and GHSV $1000 \mathrm{~h}^{-1}$. In this regard, a simulated feed mixture with a $\mathrm{CH}_{4} / \mathrm{CO}_{2} / \mathrm{H}_{2} \mathrm{O}$ reactant feed molar ratio of $1 / 0.5 / 4$ was used to carry out the mixed reforming reaction tests for producing pure hydrogen.

The results showed that the higher the reaction pressure, the higher the conversion and hydrogen recovery due to the shift effect realized in the $\mathrm{MR}$. As a result, at $350 \mathrm{kPa}$, the $\mathrm{MR}$ was able to achieve more than $60 \%$ methane conversion and around 50\% hydrogen recovery. Consequently, the results of the experimental tests were used to estimate the surface area and hydrogen production at a larger scale for the domestic gas refinery.

All in all, the following advantages could be gained with the proposed process for the domestic gas refinery:

(1) Prevent $\mathrm{CO}_{2}$ and hazardous materials emissions to the atmosphere by utilization of flare gas and flue gas as a waste product of the refinery to produce pure hydrogen in an MR.

(2) Using the benefits of the mixed reforming reaction for producing hydrogen.

(3) Low-temperature operation.

(4) The cost of natural gas used as an inlet feed of the hydrogen generation plants leads to an increase in costs; however, the flare gas is used as an inlet feed, and consequently, costs regarding natural gas feed are eliminated.

(5) By using flue gas as a source of energy, the cost of providing energy (which is the most expensive part of the hydrogen generation plants) is omitted.

(6) The exhaust flue gas is used as a feed stream to produce $\mathrm{CO}_{2}$ for the mixed reforming reaction in the $\mathrm{CO}_{2}$ recovery unit.

Supplementary Materials: The following are available online at www.mdpi.com/2227-9717/4/3/33/s1, Figure S1: The industrial furnace of the domestic gas refinery; Figure S2: Process flow diagram of the $\mathrm{CO}_{2}$ recovery unit.

Acknowledgments: The Authors would like to thank the Italian Ministry of Economic Development (MISE) for the funds received by Microgen30 project, contract number EE01_00013, to develop part of the research of this work.

Author Contributions: S.M.J., A.I. and A.B. conceived and designed the experiments; S.M.J. and G.B. performed the experiments; A.I., F.D. and S.M.J. analyzed the data; A.V., A.S. and M.R.R. contributed reagents/materials/analysis tools; S.M.J. and A.I. wrote the paper.

Conflicts of Interest: The authors declare no conflict of interest.

\section{List of Symbols and Acronyms}

$\begin{array}{ll}\text { GHG } & \text { green-house gases } \\ \text { GTL } & \text { gas to liquid } \\ \text { MR } & \text { membrane reactor } \\ \text { TR } & \text { traditional reactor } \\ \text { PEMFC } & \text { proton exchange membrane fuel cell } \\ W & \text { membrane area per unit length in the z-direction } \\ Q_{0} & \text { initial volumetric flow rate of the feed in the retentate zone } \\ E_{a} & \text { apparent activation energy } \\ J_{H_{2}} & \text { hydrogen flux permeating through the membrane } \\ P_{0} & \text { pre-exponential factor }\end{array}$




$\begin{array}{ll}P e_{H_{2}} & \text { hydrogen permeability } \\ P_{\mathrm{H}_{2}-\text { perm }} & \text { hydrogen partial pressure in the permeate side } \\ P_{\mathrm{H}_{2}-\text { ret }} & \text { hydrogen partial pressure in the retentate side } \\ R & \text { universal gas constant } \\ T & \text { absolute temperature } \\ \delta & \text { membrane thickness }\end{array}$

\section{References}

1. Fan, M.S.; Abdullah, A.Z.; Bhatia, S. Catalytic technology for carbon dioxide reforming of methane to synthesis gas. Chem. Cat. Chem. 2009, 1, 192-208. [CrossRef]

2. DoE, U.S. Waste Heat Reduction and Recovery for Improving Furnace Efficiency Productivity and Emissions Performance; U.S. Department of Energy: Washington, DC, USA, 2004.

3. Schurz, A.; Andersson, L.; Storm, H. A 12-MW gas turbine cogeneration plant fired with refinery gases. Chart. Mech. Eng. 1982, 29, 63-66.

4. Broeker, R.J. Combined-cycle cogeneration to power oil refinery. Mech. Eng. 1986, 108, 42-45.

5. Najar, S.H.; Habeebullah, M.B. Energy conservation in the refinery by utilizing reformed fuel gas and furnace flue gases. Heat Recovery Syst. CHP 1991, 11, 517-521. [CrossRef]

6. Rahimpour, M.R.; Jokar, S.M. Feasibility of flare gas reformation to practical energy in Farashband gas refinery: No gas flaring. J. Hazard. Mater. 2012, 209-210, 204-217. [CrossRef] [PubMed]

7. Rahimpour, M.R.; Jamshidnejad, Z.; Jokar, S.M.; Karimi, G.; Ghorbani, A.; Mohammadi, A.H. A comparative study of three different methods for flare gas recovery of Asalouye Gas Refinery. J. Nat. Gas Sci. Eng. 2012, 4, 17-28. [CrossRef]

8. Saidi, M.; Siavashi, F.; Rahimpour, M.R. Application of solid oxide fuel cell for flare gas recovery as a new approach; a case study for Asalouyeh gas processing plant, Iran. J. Nat. Gas Sci. Eng. 2014, 17, 13-25. [CrossRef]

9. Abdulrahman, A.O.; Huisingh, D.; Hafkamp, W. Sustainability improvements in Egypt's oil \& gas industry by implementation of flare gas recovery. J. Clean. Prod. 2015, 98, 116-122.

10. Reijerkerk, S.R.; Jordana, R.; Nijmeijer, K.; Wessling, M. Highly hydrophilic, rubbery membranes for $\mathrm{CO}_{2}$ capture and dehydration of flue gas. Int. J. Greenhouse Gas Control 2011, 5, 26-36. [CrossRef]

11. Khalilpour, R.; Mumford, K.; Zhai, H.; Abbas, A.; Stevens, G.; Rubin, E.S. Membrane-based carbon capture from flue gas: A review. J Clean. Prod. 2015, 103, 286-300. [CrossRef]

12. He, X.; Fu, C.; Hägg, M.B. Membrane system design and process feasibility analysis for $\mathrm{CO}_{2}$ capture from flue gas with a fixed-site-carrier membrane. Chem. Eng. J. 2015, 268, 1-9. [CrossRef]

13. Hassanlouei, R.N.; Pelalak, R.; Daraei, A. Wettability study in $\mathrm{CO}_{2}$ capture from flue gas using nano porous membrane contactors. Int. J. Greenhouse Gas Control 2013, 16, 233-240. [CrossRef]

14. Halmann, M.; Steinfeld, A. Hydrogen production and $\mathrm{CO}_{2}$ fixation by flue-gas treatment using methane tri-reforming or coke/coal gasification combined with lime carbonation. Int. J. Hydrogen Energy 2009, 34, 8061-8066. [CrossRef]

15. Chen, W.H.; Lin, M.R.; Leu, T.S.; Du, S.W. An evaluation of hydrogen production from the perspective of using blast furnace gas and coke oven gas as feedstocks. Int. J. Hydrogen Energy 2011, 36, 11727-11737. [CrossRef]

16. Liberatore, R.; Lanchi, M.; Caputo, G.; Felici, C.; Giaconia, A.; Sau, S.; Tarquini, P. Hydrogen production by flue gas through sulfur-iodine thermochemical process: Economic and energy evaluation. Int. J. Hydrogen Energy 2012, 37, 8939-8953. [CrossRef]

17. Rostrup-Nielsen, J.R.; Rostrup-Nielsen, T. Large-Scale Hydrogen Production. Cattech 2002, 6, 150-159. [CrossRef]

18. Wee, J.H. Applications of proton exchange membrane fuel cell systems. Renew. Sustain. Energy Rev. 2007, 11, 1720-1738. [CrossRef]

19. Ahmed, S.; Krumpelt, M. Hydrogen from hydrocarbon fuels for fuel cells. Int. J. Hydrogen Energy 2001, 26, 291-301.

20. Rabenstein, G.; Hacker, V. Hydrogen for fuel cells from ethanol by steam-reforming, partial-oxidation and combined autothermal reforming: A thermodynamic analysis. J. Power Sour. 2008, 185, 1293-1304. [CrossRef] 
21. Seo, Y.S.; Shirley, A.; Kolaczkowski, S.T. Evaluation of thermodynamically favourable operating conditions for production of hydrogen in three different reforming technologies. J Power Sour. 2002, 108, 213-225. [CrossRef]

22. Rostrupnielsen, J.R.; Hansen, J.B. $\mathrm{CO}_{2}$-reforming of methane over transition metals. J. Catal. 1993, 144, $38-43$. [CrossRef]

23. Ruckenstein, E.; Hu, Y.H. The effect of precursor and preparation conditions of $\mathrm{MgO}$ on the $\mathrm{CO}_{2}$ reforming of $\mathrm{CH}_{4}$ over $\mathrm{NiO} / \mathrm{MgO}$ catalysts. Appl. Catal. A: Gen. 1997, 154, 185-205. [CrossRef]

24. Zhang, Z.; Verykios, X.E. A stable and active nickel-based catalyst for carbon dioxide reforming of methane to synthesis gas. J. Chem. Soc. Chem. Commun. 1995, 71-72. [CrossRef]

25. Zhang, Z.; Verykios, X.E. Carbon dioxide reforming of methane to synthesis gas over $\mathrm{Ni} / \mathrm{La}_{2} \mathrm{O}_{3}$ catalysts. Appl. Catal. A: Gen. 1996, 138, 109-133.

26. Cui, Y.; Zhang, $\mathrm{H}$.; $\mathrm{Xu}, \mathrm{H}$.; $\mathrm{Li}$, W. The $\mathrm{CO}_{2}$ reforming of $\mathrm{CH}_{4}$ over $\mathrm{Ni} / \mathrm{La}_{2} \mathrm{O}_{3} / \alpha-\mathrm{Al}_{2} \mathrm{O}_{3}$ catalysts: The effect of $\mathrm{La}_{2} \mathrm{O}_{3}$ contents on the kinetic performance. Appl. Catal. A: Gen. 2007, 331, 60-69. [CrossRef]

27. Kathiraser, Y.; Oemar, U.; Saw, E.T.; Li, Z.; Kawi, S. Kinetic and mechanistic aspects for $\mathrm{CO}_{2}$ reforming of methane over Ni based catalysts (review). Chem. Eng. J. 2015, 278, 62-78. [CrossRef]

28. Li, C.; Fu, Y.; Bian, G.; Xie, Y.; Hu, T.; Zhang, J. Effect of steam in $\mathrm{CO}_{2}$ reforming of $\mathrm{CH}_{4}$ over a $\mathrm{Ni} / \mathrm{CeO}_{2}-\mathrm{ZrO}_{2}-\mathrm{Al}_{2} \mathrm{O}_{3}$ catalyst. Kinet. Cat. 2004, 45, 679-683. [CrossRef]

29. Snoeck, J.W.; Froment, G.; Fowles, M. Kinetic evaluation of carbon formation in steam $/ \mathrm{CO}_{2}$-natural gas reformers. Influence of the catalyst activity and alkalinity. Int. J. Chem. Reac. Eng. 2003, 1, 1-16. [CrossRef]

30. Abashar, M.E.E. Coupling of steam and dry reforming of methane in catalytic \& fluidized bed membrane reactors. Int. J. Hydrogen Energy 2004, 29, 799-808.

31. Froment, G.F. Production of synthesis gas by steam- and $\mathrm{CO}_{2}$-reforming of natural gas. J. Mol. Catal. A: Chem. 2000, 163, 147-156.

32. Iulianelli, A.; Liguori, S.; Huang, Y.; Basile, A. Model biogas steam reforming in a thin Pd-supported membrane reactor to generate clean hydrogen for fuel cells. J. Power Sour. 2015, 273, 25-32. [CrossRef]

33. Koo, K.Y.; Lee, S.; Jung, U.H.; Roh, H.; Yoon, W.L. Syngas production via combined steam and carbon dioxide reforming of methane over $\mathrm{Ni}-\mathrm{Ce} / \mathrm{MgAl}_{2} \mathrm{O}_{4}$ catalysts with enhanced coke resistance. Fuel Process Technol. 2014, 119, 151-157. [CrossRef]

34. Lemonidou, A.A.; Vasalos, I.A. Carbon dioxide reforming of methane over 5 wt. $\%$ Ni $/ \mathrm{CaO}-\mathrm{Al}_{2} \mathrm{O}_{3}$ catalyst. Appl. Catal. A: Gen. 2002, 228, 227-235. [CrossRef]

35. Özkara-Aydınoğlu, Ş. Thermodynamic equilibrium analysis of combined carbon dioxide reforming with steam reforming of methane to synthesis gas. Int. J. Hydrogen Energy 2010, 35, 2821-2828. [CrossRef]

36. Choudhary, V.R.; Rajput, A.M. Simultaneous carbon dioxide and steam reforming of methane to syngas over $\mathrm{NiO}-\mathrm{CaO}$ catalyst. Ind. Eng. Chem. Res. 1996, 35, 3934-3939. [CrossRef]

37. Hegarty, M.E.S.; O'Connor, A.M.; Ross, J.R.H. Syngas production from natural gas using $\mathrm{ZrO}_{2}$-supported metals. Catal. Today 1998, 42, 225-232. [CrossRef]

38. Choudhary, V.R.; Mondal, K.C. $\mathrm{CO}_{2}$ reforming of methane combined with steam reforming or partial oxidation of methane to syngas over $\mathrm{NdCoO}_{3}$ perovskite-type mixed metal-oxide catalyst. Appl. Energy 2006, 83, 1024-1032. [CrossRef]

39. Noronha, F.B.; Shamsi, A.; Taylor, C.; Fendley, E.C.; Stagg-William, S.; Resasco, D.E. Catalytic performance of $\mathrm{Pt} / \mathrm{ZrO}_{2}$ And $\mathrm{Pt} / \mathrm{Ce}-\mathrm{ZrO}_{2}$ catalysts on $\mathrm{CO}_{2}$ reforming of $\mathrm{CH}_{4}$ coupled with steam reforming or under high pressure. Catal. Lett. 2003, 90, 13-21. [CrossRef]

40. Sheng, M.; Yang, H.; Cahela, D.; Tatarchuk, B.J. Novel catalyst structures with enhanced heat transfer characteristics. J. Catal. 2011, 281, 254-262. [CrossRef]

41. Boger, T.; Herbel, A.K. Heat transfer in conductive monolith structures. Chem. Eng. Sci. 2005, 60, 1823-1835. [CrossRef]

42. Slagtern, A.; Oblbye, U.; Blom, R.; Dahl, I.M.; Fjellvag, H. In situ XRD characterization of La-Ni-Al-O model catalysts for $\mathrm{CO}_{2}$ reforming of methane. Appl. Catal. A: Gen. 1996, 145, 375-388. [CrossRef]

43. Valderrama, G.; Goldwasser, M.R.; Navarro, C.U.; Tatibouet, J.M.; Barrault, J.; Batiot-Dupeyrat, C.; Martinez, F. Dry reforming of methane over Ni perovskite type oxides. Catal. Today 2005, 108, 785-791. [CrossRef]

44. $\mathrm{Hu}, \mathrm{Y} . \mathrm{H}$.; Ruckenstein, E. An optimum $\mathrm{NiO}$ content in the $\mathrm{CO}_{2}$ reforming of $\mathrm{CH}_{4}$ with $\mathrm{NiO} / \mathrm{MgO}$ solid solution catalysts. Catal. Lett. 1996, 36, 145-149. [CrossRef] 
45. Ruckenstein, E.; Wang, H.Y. Carbon deposition and catalytic deactivation during $\mathrm{CO}_{2}$ reforming of $\mathrm{CH}_{4}$ over $\mathrm{Co} / \mathrm{Al}_{2} \mathrm{O}_{3}$. J. Catal. 2002, 205, 289-293. [CrossRef]

46. Iulianelli, A.; Liguori, S.; Wilcox, J.; Basile, A. Advances on methane steam reforming to produce hydrogen through membrane reactors technology: A review. Catal. Rev. Sci. Eng. 2016, 58, 1-35. [CrossRef]

47. Pompeo, F.; Nichio, N.N.; Souza, M.M.V.M.; Cesar, D.V.; Ferretti, O.A.; Schmal, M. Study of Ni and Pt catalysts supported on $\alpha-\mathrm{Al}_{2} \mathrm{O}_{3}$ and $\mathrm{ZrO}_{2}$ applied in methane reforming with $\mathrm{CO}_{2}$. Appl. Catal. A: Gen. 2007, 316, 175-183. [CrossRef]

48. Gigola, C.E.; Moreno, M.S.; Costilla, I.; Sánchez, M.D. Characterization of Pd-CeOx interaction on $\alpha-\mathrm{Al}_{2} \mathrm{O}_{3}$ support. Appl. Surf. Sci. 2007, 254, 325-329. [CrossRef]

49. Múnera, J.F.; Irusta, S.; Cornaglia, L.M.; Lombardo, E.A.; Cesar, D.V.; Schmal, M. Kinetics and reaction pathway of the $\mathrm{CO}_{2}$ reforming of methane on Rh supported on lanthanum based solid. J. Catal. 2006, 245, 25-34. [CrossRef]

50. Hashimoto, K.; Watase, S.; Toukai, N. Reforming of methane with carbon dioxide over a catalyst consisting of ruthenium metal and cerium oxide supported on mordenite. Catal. Lett. 2002, 80, 147-152. [CrossRef]

51. Nagaoka, K.; Seshan, K.; Aika, K.; Lercher, J.A. Carbon deposition during carbon dioxide reforming of methane-comparison between $\mathrm{Pt} / \mathrm{Al}_{2} \mathrm{O}_{3}$ and $\mathrm{Pt} / \mathrm{ZrO}_{2}$. J. Catal. 2001, 197, 34-42. [CrossRef]

52. Bradford, M.C.J.; Vannice, M.A. $\mathrm{CO}_{2}$ reforming of $\mathrm{CH}_{4}$. Catal. Rev. 1999, 41, 1-42. [CrossRef]

53. Barroso-Quiroga, M.M.; Castro-Luna, A.E. Catalytic activity and effect of modifiers on Ni-based catalysts for the dry reforming of methane. Int. J. Hydrogen Energy 2010, 35, 6052-6056. [CrossRef]

54. Subramani, V.; Sharma, P.; Zhang, L.; Liu, K.; Song, C. Hydrogen and Syngas Production and Purification Technologies: Hydrocarbon Processing for $\mathrm{H}_{2}$ Production; Wiley: New York, NY, USA, 2010; pp. 14-126.

55. Danilova, M.M.; Fedorova, Z.A.; Zaikovskii, V.I.; Porsin, A.V.; Kirillov, V.A.; Krieger, T.A. Porous nickel-based catalysts for combined steam and carbon dioxide reforming of methane. Appl. Catal. B: Environ. 2014, 147, 858-863.

56. Li, L.; Borry, R.W.; Iglesia, E. Design andoptimization of catalysts and membrane reactors for the non-oxidative conversion of methane. Chem. Eng. Sci. 2002, 57, 4595-4604. [CrossRef]

57. Rostrup-Nielsen, J.R.; Christiansen, L.J.; Bak Hansen, J.H. Activity of steam reforming catalysts: Role and assessment. Appl. Catal. 1988, 43, 287-303. [CrossRef]

58. Rostrup-Nielsen, J.R.; Sehested, J.; Nørskov, J.K. Hydrogen and synthesis gas by steam- and $\mathrm{CO}_{2}$ reforming. Adv. Catal. 2002, 47, 65-139. [CrossRef]

59. Chen, Y.; Wang, Y.; Xu, H.; Xiong, G. Efficient production of hydrogen from natural gas steam reforming in palladium membrane reactor. Appl. Catal. B Environ. 2008, 80, 283-294. [CrossRef]

60. Liu, Z.W.; Roh, H.S.; Jun, K.W. Important factors on carbon dioxide reforming of methane over nickel-based catalysts. J. Ind. Eng. Chem. 2003, 9, 753-761.

61. Bae, J.W.; Kim, A.R.; Baek, S.C.; Jun, K.W. The role of $\mathrm{CeO}_{2}-\mathrm{ZrO}_{2}$ distribution on the Ni/ $\mathrm{MgAl}_{2} \mathrm{O}_{4}$ catalyst during the combined steam and $\mathrm{CO}_{2}$ reforming of methane. React. Kinet. Mech. Catal. 2011, 104, 377-388. [CrossRef]

62. Jun, K.W.; Baek, S.C.; Bae, J.W.; Min, K.S.; Song, S.L.; Oh, T.Y. Hyundai Heavy Industries Corporation and Korea Research Institute of Chemical Technology. Patent EP 2308594 A2, 2009.

63. Wei, J.M.; Iglesia, E. Isotopic and kinetic assessment of the mechanism of reactions of $\mathrm{CH}_{4}$ with $\mathrm{CO}_{2}$ or $\mathrm{H}_{2} \mathrm{O}$ to form synthesis gas and carbon on nickel catalysts. J. Catal. 2004, 224, 370-383. [CrossRef]

64. Choudhary, V.R.; Uphade, B.S.; Mamman, A.S. Simultaneous steam and $\mathrm{CO}_{2}$ reforming of methane to syngas over $\mathrm{NiO} / \mathrm{MgO} / \mathrm{SA}-5205$ in presence and absence of oxygen. Appl. Catal. A: Gen. 1998, 168, 33-46. [CrossRef]

65. Sona, I.H.; Lee, S.J.; Soon, A.; Roh, H.; Leed, H. Steam treatment on $\mathrm{Ni} / \mathrm{Y}-\mathrm{Al}_{2} \mathrm{O}_{3}$ for enhanced carbon resistance in combined steam and carbon dioxide reforming of methane. Appl. Catal. B: Environ. 2013, 134-135, 103-109. [CrossRef]

66. Koo, K.Y.; Lee, S.; Jung, U.H.; Roh, H.; Yoon, W.L. Syngas production via combined steam and carbon dioxide reforming of methane over $\mathrm{Ni}-\mathrm{Ce} / \mathrm{MgAl}_{2} \mathrm{O}_{4}$ catalysts with enhanced coke resistance. Fuel Process. Technol. 2014, 119, 151-157. [CrossRef]

67. Shu, J.; Grandjean, B.P.A.; Van Neste, A.; Kalaguine, S. Catalytic palladium-based membrane reactors: A review. Can. J. Chem. Eng. 1991, 69, 1036-1060. [CrossRef] 
68. Iulianelli, A.; Liguori, S.; Longo, T.; Basile, A. Inorganic membrane and membrane reactor technologies for hydrogen production. In Hydrogen Production: Prospects and Processes; Honery, D.R., Moriarty, P., Eds.; Nova Science: Victoria, Australia, 2012; pp. 377-398.

69. Tereschenko, G.F.; Ermilova, M.M.; Mordovin, V.P.; Orekhova, N.V.; Gryaznov, V.M.; Iulianelli, A.; Gallucci, F.; Basile, A. New Ti-Ni dense membranes with low palladium content. Int. J. Hydrogen Energy 2007, 32, 4016-4022. [CrossRef]

70. Iulianelli, A.; Basile, A. Hydrogen production from ethanol via inorganic membrane reactors technology: A review. Catal. Sci. Technol. 2011, 1, 366-379. [CrossRef]

71. Buxbaum, R.E.; Kinney, A.B. Hydrogen transport through tubular membranes of palladium-coated tantalum and niobium. Ind. Eng. Chem. Res. 1996, 35, 530-537. [CrossRef]

72. Briceño, K.; Iulianelli, A.; Montané, D.; Garcia-Valls, R.; Basile, A. Carbon molecular sieve membranes supported on non-modified ceramic tubes for hydrogen separation in membrane reactors. Int. J. Hydrogen Energy 2012, 37, 13536-13544. [CrossRef]

73. Basile, A.; Palma, V.; Ruocco, C.; Bagnato, G.; Jokar, S.M.; Rahimpour, M.R.; Shariati, A.; Rossi, C.; Iulianelli, A. Pure hydrogen production via ethanol steam reforming reaction over a novel $\mathrm{Pt}$-Co based catalyst in a dense Pd-Ag membrane reactor (An experimental study). Int. J. Mem. Sci. Technol. 2015, 2, 5-14. [CrossRef]

74. Liguori, S.; Pinacci, P.; Seelam, P.K.; Keiski, R.; Drago, F.; Calabrò, V.; Basile, A.; Iulianelli, A. Performance of a Pd/PSS membrane reactor to produce high purity hydrogen via WGS reaction. Catal. Today 2012, 193, 87-94. [CrossRef]

75. Iulianelli, A.; Manzolini, G.; Falco, M.D.; Campanari, S.; Longo, T.; Liguori, S.; Basile, A. $\mathrm{H}_{2}$ production by low pressure methane steam reforming in a Pd-Ag membrane reactor over a Ni-based catalyst: Experimental and modeling. Int. J. Hydrogen Energy 2010, 35, 11514-11524. [CrossRef]

76. Lima, V.F.; Daoutidis, P.; Tsapatsis, M. Modeling, optimization, and cost analysis of an IGCC plant with a membrane reactor for carbon capture. AIChE J. 2016, 62, 1568-1580. [CrossRef]

77. Italiano, C.; Vita, A.; Fabiano, C.; Laganà, M.; Pino, L. Bio-hydrogen production by oxidative steam reforming of biogas over nanocrystalline $\mathrm{Ni} / \mathrm{CeO}_{2}$ catalysts. Int. J. Hydrogen Energy 2015, 40, 11823-11830. [CrossRef]

78. Iulianelli, A.; Liguori, S.; Vita, A.; Italiano, C.; Fabiano, C.; Huang, Y.; Basile, A. The oncoming energy vector: Hydrogen produced in $\mathrm{Pd}$-composite membrane reactor via bioethanol reforming over $\mathrm{Ni} / \mathrm{CeO}_{2}$ catalyst. Catal. Today 2016, 259, 368-375. [CrossRef]

79. Gooding, C.H. Scale-up of membrane systems from lab data. J. Membr. Sci. 1991, 62, 309-323. [CrossRef] 